\title{
PENDAMPINGAN PENYUSUNAN ASESMEN FISIKA BERBASIS OSN BAGI GURU SMP DI KOTA TABANAN
}

\author{
oleh, \\ I Kade Suardana, AAIA. Rai Sudiatmika, Dewi Oktofa. \\ Jurusan Pendidikan Fisika \\ Fakultas Matematika dan Ilmu Pengetahuan Alam \\ Universitas Pendidikan Ganesha
}

\begin{abstract}
ABSTRAK
Tujuan utama kegiatan P2M ini adalah 1) meningkatkan kemampuan guru pendamping pembina olimpiade OSN fisika di SMP di kota Tabanan dalam menyusun dan mengembangkan asesmen fisika berbasis olimpiade, dan 2) meningkatkan respon para peserta pelatihan terhadap pelaksanaan pendampingan penyusunan dan pengembangan asesmen fisika berbasis OSN. Untuk mencapai tujuan di atas, telah dilakukan kegiatan pengabdian kepada masyarakat dalam bentuk pendampingan yang diselenggarakan pada tanggal 27 Oktober 2012 bertempat di SMP N 2 Tabanan. Kegiatan ini diikuti oleh 15 orang guru (sains- fisika) SMP N Kota Tabana. Data yang telah dikumpulkan dengan teknik tes, observasi, teknik angket dan wawancara, kemudian dianalisis secara deskriptif. Dari hasil analisis data dapat disimpulkan bahwa 1) kemampuan guru pendamping pembina OSN fisika di SMP $\mathrm{N}$ di kota Tabanan dalam menyusun dan mengembangkan asesmen fisika berbasis olimpiade meningkat setelah kegiatan pendampingan, dan 2) para guru pendamping pembina OSN fisika di SMP N di kota Tabanan sebagai peserta pelatihan menunjukan respon positif terhadap pelaksanaan kegiatan pendampingan ini. Beberapa hal positif yang diperoleh setelah kegiatan pendampingan ini adalah 1) para guru pendamping pembina olimpiade fisika memperoleh pendalaman materi-materi fisika dalam tataran OSN, 2) para guru peserta pelatihan mengetahui teknik penyusunan dan pengembangan asesmen fisika berbasis OSN yang secara langsung dapat diterapkannya dalam membina kegiatan olimpiade, dan 3) tersedianya asesmen fisika SMP berbasis OSN yang akan dapat digunakan oleh para guru pembina dan para siswa sebagai salah satu acuan sumber belajar dalam persiapan menghadapi OSN.
\end{abstract}

Kata-kata kunci: asesmen, fisika, pendampingan, OSN

\section{Pendahuluan}

Kegiatan ini dirancang merupakan hasil tindak lanjut dari pelaksanaan kegiatan P2M yang dilaksanakan Rai Sudiatmika, dkk (2011) dimana berdasarkan hasil refleksi 
dan rekomendasi pelaksanaan pembinaan olimpiade di SMP N di Kabupaten Tabanan disarankan kepada para guru pembina agar menyediakan asesmen fisika yang berbasis olimpiade sehingga pelaksanaan pembinaan dapat lebih terarah sesuai dengan tuntutan Silabus Olimpiade Sains Nasional (OSN). Saran yang direkomendasikan ini diperkuat oleh temuan peneliti, selaku pelaksana P2M ( baik pada saat menjadi nara sumber diklat guru pendamping OSN se-provinsi Bali yang dilaksanakan Disdikpora Provinsi Bali maupun nara sumber di beberapa kabupaten di provinsi Bali sehubungan dengan pembinaan siswa menjelang pelaksanaan OSN), menunjukan sampai saat ini para guru pendamping dalam pelaksanaan pembinaan OSN di lapangan belum dapat menyediakan asesmen yang terdiri dari soal-soal dan pemecahannya yang relevan dengan tuntutan Silabus OSN yang memiliki karateristik berbeda dengan soal ujian sekolah: 1) memiliki tingkat kesukaran yang relatif lebih tinggi, setara dengan soal-soal ujian SMA, bahkan PT, 2) berubah dari tahun ke tahun, 3) soalnya lebih banyak bersifat terbuka (open-ended) menekankan pemecahan masalah dan menuntut kemampuan berpikir tingkat tinggi, dan 4) sistem evaluasi menggunakan passing grade.

Di bidang pendidikan, kabupaten Tabanan yang terletak di Bali Selatan memiliki cukup potensi dalam mengembangkan kualitas sumber daya manusia ditinjau dari segi input siswa, dukungan sarana dan prasarana pembelajaran, dan guru (jumlah guru berlatar belakang Pendidikan Fisika 7 orang dari 16 orang guru sains di tiga SMP N di kota Tabanan, yaitu SMP N 1 Tabanan, SMP N 2 Tabanan, dan SMP N 3 Tabanan). Namun kenyataannya di bandingkan dengan kodya Denpasar, kabupaten Gianyar dan kabupaten Buleleng, perolehan tiket OSN Fisika yang mewakili Provinsi Bali dari kabupaten Tabanan sekaligus sebagai duta kabupaten Tabanan untuk 2 tahun terakhir adalah 1 orang (dari 6 orang pada OSN 2010 dan 5 orang pada OSN 2011) (Dikdispora, 2010: 2011).

Salah satu ditengarai sebagai penyebabnya, siswa SMP di kabupaten Tabanan belum terbiasa mengerjakan soal-soal fisika berbasis olimpiade yang memiliki tingkat kesukaran soal yang relatif lebih tinggi, bahkan lebih mengacu pada pendalaman materi pada tingkat lebih lanjut, seperti materi-materi fisika tingkat SMA dan materi perguruan tinggi. Sedangkan penyajian materi dalam pembinaan olimpiade fisika SMP kurang mengkaji lebih mendalam terhadap materi-materi teori maupun paktek yang harus diberikan untuk menghadapi OSN. Hasil temuan Suardana, dkk (2009) dan Rai 
Sudiatmika, dkk (2011) dalam pembinaan siswa untuk menghadapi olimpiade, guru pendamping masih mengandalkan tipe-tipe soal yang ada di buku-buku SMP, kurang bersifat aplikatif kearah pemecahan masalah.

Masih kurangnya sumber belajar terutama materi fisika yang berorientasi OSN yang dilengkapi soal-soal serta pemecahannya kemungkinan disebabkan oleh masih kurangnya kemampuan guru dalam mengembangkan asesmen tersebut. Sebagai dampaknya guru dan siswa hanya mengandalkan buku-buku yang mereka miliki yang tak jauh beda dengan buku regular mereka di sekolah, tanpa pendalaman materi berorientasi OSN dan strategi pemecahan masalah.

Berkaitan dengan proses pembelajaran fisika di SMP di kabupaten Tabanan, khususnya dalam pembinaan olimpiade fisika terdapat berbagai permasalahan yang berhasil diidentifikasi dan perlu dicermati, sebagai berikut. 1. Pihak sekolah (guru pembina) belum dapat menyediakan materi ajar, latihan soal-soal dan pemecahannnya yang relevan dengan tuntutan OSN. Siswa masih mengandalkan buku-buku SMP yang telah digunakannya untuk memperdalam materi, latihan soal, padahal karakteristik soal olimpiade berbeda dengan soal ujian sekolah, 2. Penyajian materi dalam pembinaan olimpiade sains kurang mengkaji lebih mendalam terhadap materi teori maupun praktek yang harus diberikan untuk menghadapi tahapan pelaksanaan OSN.

Berkaitan dengan materi olimpiade fisika sesuai silabus OSN lebih dititikberatkan pada pengoptimalan kapabalitas keterampilan intektual siswa, terutama keterampilan pemecahan masalah yang bertujuan untuk melatih siswa untuk berpikir tingkat tinggi mencakup (1) critical thinking meliputi (kemampuan menguji, menghubungkan, mengevaluasi aspek-aspek situasi atau memfokuskan masalah pada bagian-bagian masalah, mengumpulkan dan mengorganisasikan informasi, memvalidasi dan menganalisis informasi, menentukan jawaban yang rasional, menentukan simpulan yang valid, dan menganalisis serta mengadakan refleksi), dan (2) creative thinking meliputi (kemampuan menghasilkan produk yang original, efektif, dan kompleks; mensintesis; menggeneralisasi; dan mengaplikasikan ide-ide). Keterampilan berpikir ini akan berkembang dan bisa dimiliki oleh siswa apabila dalam kegiatan pembelajaran mereka dilatih belajar dalam kegiatan pemecahan masalah. Berpikir kreatif merupakan kelanjutan dari proses berpikir kritis. menggambarkan tingkatan keterampilan berpikir sebagai berikut. 
Siswa hendaknya melatih keterampilan memecahkan masalah, untuk mengasah keterampilan berpikir tingkat tinggi seperti keterampilan analisis, keterampilan mengevaluasi dan keterampilan memetakan konsep adalah sebagian dari kemampuan berpikir yang atributnya dapat ditanamkan dalam pembelajaran. Sasaran hasil kemampuan berpikir tingkat tinggi menetapkan pencapaian siswa yang memerlukan informasi aplikasi, analisa, sintesis, dan evaluasi.

\section{Metode Pelaksanaan Pengabdian}

Metode dan strategi yang digunakan dalam pelaksanaan kegiatan ini adalah sebagai berikut. 1. Informasi, tanya jawab, dan diskusi. Metode ini dimaksudkan untuk memperdalam pengetahuan dan pemahaman guru pendamping pembina olimpiade dalam penyusunan dan pengembangan asesmen fisika berorientasi OSN. Pemberian informasi melalui seminar yang diberikan oleh nara sumber dari tim pembina olimpiade fisika provinsi Bali dan melibatkan dosen Jurusan Pendidikan Fisika FMIPA Undiksha. 2. Latihan dan Praktek. Metode ini dimaksudkan untuk merealisasikan teori yang diperoleh melalui infomasi, tanya jawab dan diskusi. Dalam pelaksanaannya, peserta secara bersama-sama dalam bentuk kerja kelompok menyusun dan mengembangkan asesmen fisika berorientasi OSN., yang dalam kegiatan pendampingan ini secara langsung dibimbing oleh nara sumber sumber dari tim prmbina olimpiade fisika provinsi Bali dan melibatkan dosen Jurusan Pendidikan Fisika FMIPA Undiksha.

Pihak-pihak yang terkait dengan kegiatan ini adalah sebagai berikut. 1. Disdikpora Kecamatan Tabanan, yang bertanggung jawab langsung terhadap segala kegiatan yang dilakukan oleh sekolah-sekolah SMP N di Kota Tabanan. Secara tak langsung Dinas Pendidikan akan merasakan manfaat kegiatan ini, karena kegiatan ini bertujuan untuk meningkatkan kualitas pendidikan, khususnya dalam mata pelajaran fisika. 2. Universitas Pendidikan Ganesha, yang merupakan instansi dari tim pengabdian sebagai penghasil tenaga pendidik. 3. Sekolah-sekolah SMP N di Kota Tabanan, dimana para gurunya mendapat pelatihan langsung dalam kegiatan P2M ini.. Kegiatan ini akan bermanfaat langsung bagi sekolah-sekolah yang bersangkutan, karena setelah mengikuti kegiatan ini para guru akan langsung menerapkan pengetahuan, keterampilan serta pengalamannya di sekolah tersebut. 
Terkait dengan hal ini, khalayak sasaran yang strategis dan tepat untuk dilibatkan dalam kegiatan ini adalah guru pembina olimpiade fisika SMP N di kota Tabanan (SMP N 1, SMP N 2, dan SMP N 3) yang berjumlah 21 orang. Kegiatan ini dipusatkan di SMP N 2 Tabanan. Data yang diperlukan dalam kegiatan ini adalah: (1) kompetensi penyusunan asesmen fisika beserta solusi berorientasi OSN, dan (2) kompetensi pengembangan produk- asesmen fisika berorientasi OSN. Data dikumpulkan teknik observasi, teknik pencatatan domumen, dan teknik angket dan wawancara. Semua data dalam kegiatan ini dianalisis secara deskriptif dan interpretatif. Penyimpulan mendasarkan diri pada nilai rata-rata dan simpangan baku masing-masing data dan interpretasinya. Kriteria keberhasilan yang diacu sebagai dasar mengambil keputusan dalam kegiatan ini didasari oleh standar penilaian yang digunakan untuk masing-masing data yang akan dikumpulkan.

\section{Hasil dan Pembahasan}

Kegiatan ini dilaksanakan dalam bentuk pendampingan melalui kegiatan seminar dan lokakarya yang dengan melibatkan 21 orang guru fisika SMP N di kota Tabanan. Kegiatan ini dirasakan sangat penting mengingat kegiatan ini merupakan momen yang sangat penting bagi para guru pembina untuk meningkatakan kemampuannya sebagai calon pembina olimpiade fisika SMP agar dapat menghasilkan siswa yang cerdas dan kompetitif yang mampu bersaing baik di tingkat nasional dan intenasional, mengingat propinsi Bali adalah salah satu propinsi yang sangat diperhitungkan mutu lulusannnya di tingkat nasional. Momen melalui seminar-lokakarya seperti ini sangat jarang dilakukan, sehingga diharapkan para guru dapat mengembangkan diri mereka tentunya sebagai calon-calon pembina fisika SMP di sekolah mereka masing-masing.

Pelaksanaan kegiatan ini menghadiri pembicara dari tim pembina olimpiade propinsi Bali dan juga dosen Jurusan Pendidikan Fisika FPMIPA Undiksha, dengan makalahnya berjudul “ Teknik penyusunan asesmen sains fisika berorientasi OSN". Presentasinya diawali dengan menyampaikan pentingnya startegi ini diketahui selaku Pembina di sekolahnya mengingat soal-soal fisika OSN memiliki karateristik berbeda dengan soal ujian sekolah: 1) memiliki tingkat kesukaran yang relatif lebih tinggi, setara dengan soal-soal ujian SMA, bahkan PT, 2) berubah dari tahun ke tahun, 3) soalnya lebih banyak bersifat terbuka (open-ended) menekankan pemecahan masalah dan 
menuntut kemampuan berpikir tingkat tinggi, dan 4) sistem evaluasi menggunakan passing grade. Dalam penyampaian makalahnya, nara sumber menekankan langkahlangkah yang ditempuh dalam penyusunan asesmen fisika berbasis OSN, sebagai berikut. 1) Mengkaji silabus OSN. 2) Menetapkan standar kompetensi, kompetensi dasar, dan indikator capaian hasil belajar yang lebih ditekankan pada penggunaan konsep, teori, hukum untuk memecahkan masalah. 3) Membuat kisi-kisi dan kartu soal berdasarkan cakupan materi dalam silabus OSN. 4) Melalui diskusi pleno, melakukan uji (tentang kelayakan soal) oleh teman sejawat dan nara sumber. 5) Memilih soal yang telah teruji. 6) Membuat solusi dari soal yang telah teruji. 7) Mendokumentasi soal dan solusinya Diakhir presentasinya, diberikan cara mengembangkan soal-soal OSN dengan cara pemetaan soal OSN dari tahun ke tahun agar para guru tahu bagaiamana cara mengembangkan berdasrkan soal-soal yang telah ada.

Selama sesion tanya jawab seputar materi seminar, ada beberapa pertanyaan terungkap dari peserta pelatihan yang pada intinya mengungkapkan kesulitan dalam menyusun dan mengembangkan soal-soal fisika berorientasi OSN karena beberapa alasanmasih antara lain: 1) masih sulitnya para guru memperoleh/mengakses informasi seputar soal-soal fisika, 2) sulitnya mempredeksi soal-soal olimpiade yang memang memiliki karaketeristik berbeda dan tingkat kesukaran yang lebih dibandingkan dengan soal-soal fiiska umumnya, dan 3) keterbatasan kemampuan guru dalam pemahaman materi aplikasi. Beberapa saran dan kritik juga terungkap dalam sesion tanya jawab ini adalah 1) kegiatan model ini dapat dijadikan program rutin bagi jurusan Pendidikan Fisika, tidak semata diadakan bila ada proyek penelitian/pengabdian, karena kegiatan model ini dapat dijadikan ajang bagi para guru dan dosen untuk bersama-sama melakukan kajian lebih mendalam tentang prediksi dan pemecahan soal-soal olimpiade yang secara langsung dapat membantu kesulitan guru dalam pembinaan olimpiade, 2) mengharapkan jurusan Pendidikan Fisika sebagai fasilitator untuk melaksanakan kegiatan model ini dengan mendatangkan nara sumber dari pusat, seperti Prof. Yohanes Surya, Ph.D selaku Ketua TOFI Indonesia, dengan harapan diperolehnya strategi yang lebih jitu dalam menghadapi seleksi olimpiade baik tingkat kabupaten-kota, propinsi, nasional dan internasional. Terhadap pertanyaan, saran dan kritik di atas, nara sumber memberikan tanggapan sebagai berikut. Khusus untuk pembinaan menuju olimpiade fisika, sebaiknya dibentuk club-club fisika yang keanggotaannya terdiri dari siswa-siswa 
yang memang berminat dan mencintai fisika, karena jika minat fisika siswa dapat ditumbuhkan maka fisika akan merupakan "kebutuhan" bagi siswa bukan sekedar "kewajiban" untuk mendapatkan hasil yang lebih baik. Kegiatan ini jangan dijadikan ajang bisnis, dengan kata lain keanggotaan club ini tidak mesti banyak orang. Peningkatan kemampuan akademik guru juga perlu ditingkatkan sebagai pembina di sekolah mereka masing-masing, dengan harapan melalui peningkatan kemampuan akademik ini guru akan lebih mampu mempredikasi dan mampu melakukan pengembangan soal-soal olimpiade dan dapat menggunakan strategi pemecahan masalah dengan baik. Terhadap kritik dan saran, akan diupayakan bahwa jurusan Pendidikan Fisika FPMIPA Undiksha menjadikan model kegiatan ini sebagai program rutin jurusan, termasuk fasilitator bagi guru pembina dalam mengembangkan diri dan membantu guru dalam kendala pemecahan masalah fisika. Dalam session pelatihan dilakukan pemetaan dan identifikasi soal-soal fisika OSN, teknik penyusunan dan tahap pengembangannya. Telah terdokumentasi beberapa soal fisika berorientasi OSN serta solusinya untuk beberapa pokok bahasan

Berdasarkan hasil yang diperoleh dari pelaksanaan kegiatan ini menunjukan secara umum kemampuan peserta pelatihan dalam menyusun asesmen fisika berorientasi OSN mengalami peningkatan yang cukup berarti jika dibandingkan dengan sebelum mereka mendapat pelatihan model ini. Hal ini terlihat dari hasil diskusi selama penyajian makalah, di mana hampir sebagian besar peserta pelatihan mengungkapkan mereka sangat senang diberikan teknik dalam menyusun asesmen fisika berorientasi OSN, Di samping itu juga terungkap masih kurangnya kemampuan guru dalam menerapkan strategi pemecahan masalah karena tidak tahunya guru tentang startegi pemecahan masalah model ini. Dalam menyelesaikan soal-soal yang diajarkan pada siswa, guru masih menerapkan model penyelesaian soal secara konvensional, dengan menuliskan : diketahui, ditanya, dan jawab, tanpa pernah mengajak siswa untuk memaknai soal lebih lanjut, apalagi menggolongkan soal-soal tersebut ke dalam masalah akademik dan masalah dunia nyata. Terungkap juga faktor pendidikan dan spesialisasi bidang studi guru juga sangat menentukan tingkat keberhasilan guru dalam pemahaman materi seminar ini. Banyak guru yang tidak berlatar belakang pendidikan fisika atau ilmu fisika membina kegiatan olimpiade fisika, dan sebaliknya. Ungkapan-ungkapan ini sangat relevan dengan hasil perolehan data kemapuan peserta pelatihan dalam teknik dalam 
menyusun asesmen fisika berorientasi OSN, terutama dalam tahap membuat penyelesaian soal-soal dan tahap pengembangannya. Rata- rata baru 55\% peserta yang mampu menyelesaikan soal-soal dan mampu mengembangkan soal-soal yang telah dibuat dengan baik dan benar setelah mengetahui teknik penyelesaian soal soal OSN.

Hasil pelaksanaan kegiatan ini diharapkan memberikan imbas positif terhadap pelaksanaan pembinaan olimpiade fisika di sekolah mereka masing-masing sehingga diharapkan wakil Bali dalam bidang fisika makin banyak kuantitas dan kualitasnya yang mampu berperan baik di tingkat nasional dan internasional. Respon para guru Pembina OSN sangat positif terhadap model kegiatan ini sangat positif, apalagi para guru yang jauh dari Perguruan Tinggi yang terlibat dalam kegiatan pembinaan OSN tingkat provinsi Bali. Ini terbukti dari keikutsertaan para guru Pembina OSN dalam kegiatan P2M. Berdasarkan undangan yang telah diedarkan dengan cakupan guru-guru sains di kota Tabanan (SMP N 1, SMP N 2, dan SMP N 3 Tabanan) yang direncanakan hanya 12 orang guru sains ternyata setelah dilaksanakan kegiatan ini P2M ini dikuti oleh 21 orang guru sains dengan 4 orang guru sains berasala dari luar kota Tabanan, yaitu 2 orang guru sains dari SMP N 2 Kediri, 1 orang guru sains dari SMP N 5 Baturiti, dan 1 orang guru sains dari SMP 1 Baturiti (lampiran daftar hadir). Mereka berharap model kegiatan P2M ini agar dilaksanakan secara regular sehingga pola pembinaan yang dilakukan guru-guru di sekolahnya dapat ditingkatkan kualitas karena para guru secara regular memperoleh penyegaran, apalagi kegiatan model yang telah dilakukan ini hanya mengkontribusikan pikiran dana tenaga, tanpa dipungut dana.

\section{Penutup}

Beberapa hal yang dapat disimpulkan dari pelaksanaan kegiatan P2M ini adalah sebagai berikut .1) Kompetensi para guru pendamping pembina OSN fisika SMP N di kota Tabanan dalam penyusunan dan pengembangan asesmen fisika berbasis OSN dapat ditingkatkan setelah kegiatan pendampingan ini dilaksanakan. 2) Respon guru-guru pendamping pembina OSN fisika SMP $\mathrm{N}$ di kota Tabanan sangat positif terhadap pelaksaaan kegiatan ini.Beberapa hal yang disarankan dari hasil kegiatan ini, sebagai berikut. 1) Guru-guru pendamping pembina olimpiade fisika hendaknya lebih memantapakan pemahamannya tentang pemahamn materi fisika berorientasi dan lebih mengajarkan strartegi pemecahan masalah dalam pembinaan olimpiade fisika anak 
didiknya. 2) Melihat antusias keikutsertaan para peserta perlu diupayakan langkah yang lebih konkrit terutama oleh Dinas Pendidikan Kabupaten Tabanan dengan bekerja sama dengan jurusan Pendidikan Fisika FPMIPA Undiksha untuk melakukan kegiatan pelatihan model ini secara terprogram dalam upaya meningkatakan kualitas dan kuantitas siswa-siswa SMP meraih tiket sebagai peserta olimpiade tingkat nasional dan internasional

\section{DAFTAR PUSTAKA}

Disdikpora. 2011. Laporan Pelaksanaan OSN 2011. Denpasar: Provinsi Bali

Finegold, M \& Mass, R. (1985). Diffrences in Processes of Solving Physics Problems Between Good Physics Problem Solver and Poor Physics Problem Solver. Research in Science and Technological Education. Vol. 3.

Garrett, R.M. Satterly, D. Gill Perez, D. \& Marttinez Torregosa, J. 1990. Turning Exercises into Problem: An Experimental Studi With Teachers in Training. International Journal of Science Education Vol. 12, No. 2.

Kibbel, 1999. How do you approach a physics problem? Physics Education 34 (2).

Nurkancana, W. dan Sunartana, PPN. 1992. Evaluasi Hasil Belajar. Surabaya: Usaha Nasional.

Reif, F. 1995. Milikan Lecture 1994: Understanding and Teaching Important Scientific Thought Processes. American Journal of Physics. Vol 63, No.1, January, 1995.

Suardana, I.K. 2010. Implementasi Strategi Pemecahan Masalah Dengan Setting GI Untuk Meningkatkan Hasil Belajar Mahasiswa Pada Mata Kuliah Fisika Dasar 4. Laporan Penelitian. Undiksha

Rai Sudiatmika. dkk. 2011. Pelatihan Penerapan Strategi Pemecahan Masalah dan Penyegaran Materi Menuju Olimpiade Fisika Bagi Guru-guru SMP di Kabupaten Tabanan. Laporan P2M. Undiksha 